\title{
Performance, Pedagogy, Potential: Utopian Performance as Community-Based Education
}

\author{
Leigh Anne Howard \\ University of Southern Indiana
}

\begin{abstract}
This article examines the intersection of critical pedagogy, service-learning, and interactive performance epistemology to describe the impact performance events and processes have on student learning. Specifically, this research extends Jill Dolan's concept of utopian performance and illustrates the potential of performance not only to generate a utopian impulse essential to social change and transformation but also to stand as an intervention for social change. It clarifies the potential of utopian performance to change people, provoke action, and stand as an intervention.
\end{abstract}

Advocates of critical pedagogy have argued educating students to read cultural codes critically and creatively can establish habits of inquiry needed to decipher social interactions and the historical structures shaping those interactions (Fisher, 2001; Giroux, 1989, 1992; hooks, 1994a, 1994b; Trend, 1992). These scholars assert education is not only what happens within the confines of a classroom but also an introduction to the life and world beyond campus. Furthermore, these scholars reconfigure the role of the teacher from one who provides facts to one who transforms by facilitating student experience (Trend, 1992). Transformative teachers abandon the "sage on the stage" routine (Novek, 1999, p. 234); rather than telling students what to do or think, they teach students how to think, then do. They insist the role of the student should correspondingly shift from a passive recipient of knowledge to a collaborative partner. Such pedagogy is not only critical in nature but also public in form and focus. Given these aims, it is hardly surprising that critical pedagogues see traditional education as inadequate when it comes to encouraging students to take part in their communities (Novek, 1999).

Educators wishing to follow the precepts of critical pedagogy have encountered difficulties in praxis. Some face opposition from university administration due to the political stance inherent in critical pedagogy. Others face skepticism about the quality of such an education by arguing this approach distracts students from learning professional skills. Yet others find translating critical pedagogy from a teaching philosophy into application confusing. Nevertheless, advocates of critical pedagogy persevere. If schools, as Giroux and others have suggested, are sites that preserve hierarchies and inscribe cultural knowledge, then they can also serve as sites of liberation. Thus, our challenge as educators is to identify ways to develop forms of inquiry to stand at the forefront of such liberation.

By exploring the intersection of critical pedagogy, service-learning, and interactive performance epistemology, I establish a classroom culture steeped in a collective learning that can empower students and instill habits to prepare them for the world beyond the college campus. Students get involved in their learning and the learning of others while becoming engaged in their community. Because they perform, students do more than "take notes"; they become co-producers of knowledge and explore ways to be agents in community issues. Moreover, by using performance as an embodied epistemology, one uniquely expressive in nature, I situate education as (a) a critical and performative mode that invites student exploration and (b) a dialogic mode that facilitates learning so that all participants shape understanding. By using performance and service-learning in support of critical pedagogy, I emphasize the potential of performance as a utopian product and process, one essential to social change and shifts in cultural politics.

\section{Performance as Praxis}

Because I am a performance studies scholar as well as a critical educator with deep convictions about service-learning, I combine theory and concepts from applied interactive theater, community activism, civic engagement, and critical pedagogy to better understand how I might be a better teacher: one focused on student experience, learning outcomes, scholarly productivity, and community needs. This study is an extension of that activity in that it formally documents the results of a union 
between applied interactive theater, community activism, service-learning, and critical pedagogy. In short, I situate performance as a form of critical pedagogy and as an intervention in the world in which we live. By engaging performance in a community setting as the structure for service-learning activities, students encounter unfamiliar issues and think about familiar ones in a new way.

Mary Frances HopKins (1995), Kristin Langellier (1986), and Kay Ellen Capo (1983), as well as Mary Strine, Beverly Whitaker Long, and Mary Frances HopKins (1990), among others have explained that performance has more revolutionary functions than "doing," "fulfilling," and "furnishing" (Long \& HopKins, 1982, p. xiii). As a result, over the past 40 years, scholars have explored performance in the service of psychosocial and sociopolitical transformation (e.g., Boal, 1985; Capo, 1983; Conquergood, 1992; Fox, 1986; Howard, 2013; Rich \& Rodriguez, 2007; Rohd, 1998). As a psychosocial exploration, performance is a method of self-understanding or a tool for personal change. Performance provides individuals with an experiential, communicative tool to express what might otherwise be inexpressible. In the psychodynamic tradition of Jacob Moreno (1946), this paradigm establishes performance as a tool for therapy. Leland Roloff (1983), Ann Cattanach (1992), Anna Chesner (1994), Joke Meillo (1990), Brenda Meldrum (1994), and David Williams (1983) have explored the therapeutic benefits of performing and indicate that performance helps individuals recognize problems and identify emotional responses that heal.

Another way performance has demonstrated its ability to transform stems from our socio-political uses of performance. In some ways, all theater is social dialogue (Langellier, 1986), and all theater serves as a source of collective memory (Hermassi, cf. Capo, 1983, p. 437). Performance is a sociopolitical process because it serves as an indicator of social change as it illuminates problems, encourages awareness or dissent, and serves as a forum for civic discourse. Victor Turner (1988) elaborates on performance's "reciprocal and reflexive" characteristics when he suggests that performance is "often a critique, direct or veiled, of the social life that grows out of it, an evaluation ... of the way society handles history" (p. 22).

In the quest to understand performance's more general capacity for transformation, performance practitioners have conducted quantitative research to find out what and how audience members learned from performance. For example, studies have indicated how audience members interpret, evaluate, and utilize performance in relation to the context in which those performances occur. These performances have assessed changes in audience members' perceptions, attitudes, and/or behaviors about social issues, including homophobia (Fuoss, Kistenberg, \& Rosenfeld, 1992), step family issues (Miller Rassulo \& Hecht, 1988), date rape (Mann, Hecht, \& Valentine, 1988), drug abuse, marital problems, and HIV/AIDS (Howard, 2013; Jackson, 1993).

With its rich capacity for transformation, performance teaches us to examine our values and beliefs, to hone our ability to empathize, and to understand our connections to the larger world. Jill Dolan (2005) uses the term "utopian performances" to describe performances that depict visions of an improved world or those that create conditions that suggest the need for social reform (pp. 5-6). However, that description barely describes the capacity of performance to generate transformation. Thus, although traditional drama has persistently pointed out the need for change or it has indicated that indeed a change has occurred, it has done so without teaching us how that change might take place. For example, audience members may be left to infer that had characters made different decisions, the story would end differently. We learn the moral of the story; however, we do not learn what specific action or behavior could have changed the outcome. We do not get a preview of the alternative decision-making process. We learn that problems have solutions, but we rarely learn what the solutions are, and more importantly, we do not obtain the opportunity to create and test those solutions. Thus, these performances stop short of exploring the specific actions a person can take to become an agent who can and will enact change.

Interactive performance praxis, including the work of Augusto Boal (1985, 1992, 1995, 1998), Berenice Malka Fisher (1994, 2001), Jonathan Fox (1986), Michael Rohd (1998), and Jeff Wirth (1994), offers participants the opportunity to take action. In some instances, the work means practicing change; performance, then, becomes a rehearsal for life (Boal, 1985, 1992). In other instances, however, performance can be the change. Wirth describes this function of interactive theater by explaining the difference between theater that is reactive and that which is proactive. Reactivity suggests responding and observing whereas proactivity entails collaborating with others. Interactive theater requires not just observing the action but living it, and not just suspending disbelief but investing in the belief with mind, body, and spirit (Wirth, 1994).

Interactive theater offers a response to Dwight Conquergood's (1992) summons for performance that revolutionizes. Calling performance "the new 
frontier for staking joint claims to poetics and persuasion, pleasure and power, in the interests of community and critique, solidarity and resistance," Conquergood (1992) notes that performance has a more urgent function than a mimetic perspective that reflects our understanding (p. 80). Conquergood posits performance as a site for decentering power and for renewing commitment to social change. He uses "kinesis" to convey this urgent motivation to "break" and "remake" oppressive social structures. As kinesis, Conquergood (1992) argues, performance does more than generate awareness; it reveals an exigence to break and remake social structures. Langellier (1999) concurs when she explains performance as an intervention between the experience and how we relay the experience; this intervention requires active engagement and critical dialogue.

Augusto Boal's techniques pose one example of performance as a rehearsal for change, an intervention to produce change, and evidence of change. While Boal's early work is socio-political in nature and his later work more closely resembles theater that is psychosocial, Boal consistently insisted that theater can be a mode of action and a rehearsal for life. In this mode, performance is a proactive tool, a way to plan what to do when a situation arises, not a reflection of what happened. Boal (1985) created (and continued to adapt) his Theatre of the Oppressed techniques to give people an alternative language to discuss, analyze, and resolve oppressions. At first, he developed a series of games and exercises to offer those who were "oppressed" or voiceless a mode for expressing dissatisfaction with social and political structures. When Boal (1995) first developed the Theatre of the Oppressed, for example, he sought to liberate people from "concrete, visible oppressions" (p. 8), such as poverty, hunger, and political anarchy, that are prevalent in developing countries. His early techniques focused on movement exercises that establish community and that serve as building blocks for his Image Theater, Invisible Theater, and Forum Theater. Using these methods, Boal encouraged people to think and analyze rather than feel and react. In doing this work, participants understand that if people want to enact change, they must engage with the problem and find solutions rather than hope someone else might determine and enforce a resolution (Boal, 2001).

Interactive performance is a public, critical practice that encourages educators to explore possibilities (Madison, 1998). Just as Freire (1968) recognized dialogue, caring, community, courage, ethics, and responsibility as part of a pedagogy of freedom and Denzin (2006) references similar characteristics when describing a pedagogy of hope, performance practitioners establish performances of freedom and hope when performances display social behaviors and structures, interrogate the consequences of those behaviors and structures, and (re)position the participants as social agents (citizen-activists) with knowledge and will to transform. As Alexander (2006) observes, this type of transformation is only possible when performance pedagogy is

seen as a complex and productive site of possi-
bility that both disrupts and transforms the pro-
cess of knowing in the reified location of the
classroom and, maybe more importantly, in the
broader social, cultural, and political contexts
of everyday life. (p. 254)

When aligning the capacity of interactive performance with the transformative impulse, we recognize utopian performances as those that do more than display desirable social behaviors or illustrate the need for change in an Aristotelian sense. Utopian performances tell us how to make a better world possible by interrogating behaviors, critiquing their consequences, and demanding change. They move people toward a more critical stance, one that precedes action, and they (re)position participants as social agents. This extension of Dolan's ideas shift utopian performance away from its reliance on the performed text toward how people change personally and socially in response to the performance and by way of performance. Utopian performances, then, do not stem from the performance text but from how people respond to the text. Langellier (1983) suggested something similar when she emphasized audiencing as a function in contrast to the role of audience member.

In addition, utopian performances generate dialogue between all participants - performers and audience members alike. When we acknowledge the impact such performances have on performers as well as audience members, we continue to expand the impact of our work and increase its potential for interaction and change (Howard, 2004, 2013). By extending Dolan's concept of utopian performance, we recognize the potential of performance to generate a utopian impulse for those in the performance and/or the audience.

We need to better understand the epistemological potential of performance to generate that utopian impulse. How can performance, as an applied form and process, be used not only to teach people about course content and about the need for social change but also to prepare for, make, or be the change? By aligning utopian performance with servicelearning, the student-activist-citizen may embody social experiences, communicate them to a public 
to ensure a richer understanding of the community, and be a force for meaningful personal and social change.

\section{Designing the Community Engagement Project}

The project discussed here began in 2001 as a partnership with a satellite branch of a local youth club (YC) to support the curriculum associated with an introductory performance studies course. This partnership was structured to meet both academic and community needs. The project extended the university's commitment to the region beyond its traditional relationships with business/industry and arts/heritage non-profit organizations. More importantly, the project was a concrete way for university students to actively practice or apply course concepts. Furthermore, students were encouraged to increase their personal involvement in civic life; to think critically and creatively to solve problems; and to become smarter about managing, interpreting, assessing, and acting on information. For the YC, the partnership fulfilled other needs. Our project complemented the organization's programming related to literacy and decision making. The club's location discouraged many organizations and individuals from volunteering time or developing programs. Over the 14 years of this project, our partnership was the only ongoing programming at this branch site by an outside agency or organization.

The performance project was a required component of the course. Each semester I worked with university students to create five, one-hour interactive sessions with YC members. Each session started with warm-up activities adapting Augusto Boal's (1992) Games for Actors and Non-Actors. Then, university students partnered with YC members for a unit-related activity. These activities included using performance to examine poetry, folktales, and ghost and family stories. In addition, the group created performances about topics such as disability, peer pressure, and decision making. Each session ended with a debriefing conversation with the YC members.

\section{Assessing the Impact of Performance as Community Engagement}

Assessment was divided into two sections: assessment of service and assessment of learning. Service was assessed informally through postactivity discussions by the university students, a semester-end conversation with the unit director of the YC, and an informal survey interview with the YC members. The evaluation of learning - and data for this research - was based on two sourc- es: field reports and a final paper completed by the university students. Kolb's (1984) experiential learning model was used to structure the project's learning assessment. In the first stage, concrete experience, the university students visited the $\mathrm{YC}$ as a class and used performance to interact with the club members. After each visit, the university students recorded reflective observations, corresponding to Kolb's second stage, about their experiences in a short field report. Each reflection was guided by an observation prompt connected to the learning objectives for the course. As the semester progressed, the prompts became more abstract, approaching Kolb's third stage, abstract conceptualization.

I analyzed 735 pages from 452 field reports, gathered over an eight-year period (2006-13) from 162 students. The longitudinal strategy was developed to provide information about the project's impact beyond the span of a semester with one set of students. Following Creswell (1998) and Strauss and Corbin (1998), I began analysis by looking at descriptive data, or the way student participants described their experiences and ideas connected to the service-learning work. Specifically, I isolated responses in the field reports that indicated student awareness, action, or change. Every field report was examined; all data were placed in an exclusive category. Then, I divided up the descriptive data, linked them to similar data, and developed emergent, inductive categories of student behavior. These behavioral categories were then associated with the broad goals of utopian performance to create social awareness or to stand as a change in personal behavior. As the analysis progressed, the data pointed to a third emergent category related to performance as a social intervention. By the end of the coding, a fourth category encompassing behaviors that suggested a lack of change had emerged. Four primary emergent interpretative categories utopian performances change people, utopian performances provoke action, utopian performances stand as an intervention, and performance praxis is not perfect - serve as the foundation for the results of this study. Within each primary category, several subcategories emerged to show the range of actions that illustrate the emergent categories. Quotations were selected from the field reports to exemplify the range of responses and to verify theoretical saturation in the data collection and coding.

\section{Utopian Performances Change People}

Performance has the capacity to instill awareness in audience members and to suggest attitudes and behavior needed for personal development. However, if performance is to have an impact in 
terms of creating the vision and reality of a better world, then these performances must situate people as agents who can make change and hone skills to improve their individual footprint. Personal awareness and change, then, are the first step toward a powerful utopian performance.

Understanding service-learning. One major change resulting from this project involved a shift in how students understood the role of servicelearning. At first, the students saw themselves as providing a service to children. As the university students established relationships with the YC members, the students learned that the project brought benefits for all the participants, rather than being a service the university students brought to the children of the club. The students explained the project "was fun for them and us" and that "it is important to realize that children can teach us just as much as we can teach them." Another student wrote: "These kids taught me so much. I hope we taught them something. I don't think we were the only ones learning." Some students admitted they disliked this project at first:

I am going to be honest. I was not really looking forward to going to YC. But after I got involved in some of the activities with the children, I started to change my mind. I saw how much the children loved it. It's not like we did a whole lot, either, and they appreciated it. I remember walking to my vehicle and the little girl that I worked with ran over and gave me a hug. I did not do much in my eyes, but apparently, it meant a lot to those children. I opened my eyes to the fact that we can learn from the community and make it a better place in the process.

By the end of the project, the students reported a change in their thinking about service-learning or community-based projects. Some noted the difference between service-learning and volunteer work:

I have done many projects throughout my four years in college, but going to the club was different. It wasn't the type of service where the people receiving the service were the only ones to benefit. Going to the club was more than community service; it was an opportunity to learn.

Recognizing social agencies. By working with the children in the YC, the students also developed awareness about social agencies and their role in the community. Their impressions falling into this category also emphasized their liminal existence between town and gown, or as a temporary migrant who lived there but didn't live there. Consequently, they recognized their disconnection from the larger community surrounding campus. Many of the students had no knowledge of the YC prior to our project, nor had they participated in volunteer or service-learning activities. One student said: "I had heard of YC but I did not know there was location three minutes from my own home." By and large, however, for many students, this project was their first encounter with social agencies and their function in communities. The students explained: "I have clearly seen these agencies are vital to the community and its members" and "I am convinced my small town needs this kind of club." In some instances, the project corrected erroneous assumptions about the work of social agencies; prior to the service-learning project, some students thought such organizations were a "free daycare for children," but as a result of their service-learning project, they revised those ideas:

\section{I didn't realize it was not just for children who are too young to be by themselves. There are daily activities for older children and scholar- ships for graduates who want to continue their learning in college.}

The students moved beyond awareness by questioning and reconsidering their assumptions about class and social service agencies. One student wrote, prior to the project, that he or she thought the YC was "where low-income people put their kids after school . . . I now see how they are very beneficial for the children." By becoming familiar with social agencies and their goals, the students also were confronted with their own assumptions ones often formed with little familiarity with the issues - about race, class, and privilege. By working with the YC members, they not only saw a need for social agencies, but they also identified characteristics of such programs and why they were needed.

Embracing empathetic reciprocity. Performance encouraged students to develop empathetic reciprocity, a transactional approach to empathy (Howard, 2013). Empathetic reciprocity emerges from an interaction when one is receptive to others and possibilities while maintaining an authentic subject position. Much of this change stemmed from the identification students developed between themselves and the YC members. Many explained they liked the project because it "reminded me of when I was young" or "I like to get in touch with my inner child." However, the university students also approached identification in even more complex ways. One associated how the YC members felt about the students with the way they themselves felt about older people in the past: "I remember when I was in grade school and I would go watch high school football games, 
and I thought those guys were gods" or "[w]hen I was growing up I still have memories of visiting a college chemistry department on a field trip, and that memory is still with me. I hope their experience with us will stay with them." The university students saw direct links between their experiences and those of the YC members; this type of identification evolved over time as they made connections which required a response other than a detached sympathy that separates.

Developing key skills. The project also changed the students by providing them with an opportunity to develop key skills - adapting texts for different audiences, solving problems, making decisions, thinking critically, and planning programs. One learning outcome related to course content was to help the students understand how to adapt literature for different audiences. In general, the students started with the assumption that the performance would be the same for their peers and the children. The first performance proved how inaccurate the assumption was and how they needed to modify their performance if they were to retain the interest of their younger, more critical audience:

When I performed in class, I knew my peers were going to be quiet and pay attention no matter how I performed. The children were not the same. I realized during my first stanza I was going to have to get into it. I think had I gone into class with the same mentality I would have done better on that performance.

Another wrote: "The audiences were so different. It was like performing a different piece altogether. In class your peers just hope you get through, and at the club they want to hear the story and they really paid attention." Another student wrote that she concentrated on her performance for her peers because that was the performance that would earn her the grade for the assignment, but when she got to the club she quickly realized more was required: "I was really focusing on doing well for the class, but I needed to focus on the kids. They really paid attention to voice and pauses and dramatic effect." The students analyzed the experience of performing the same text in two locations to two different audiences; thus, they demonstrated the acquisition of a central learning outcome for the course. They also admitted the need for making changes because "performing the two texts to different audiences has shown how the audience may actually influence how a person should perform" and "studying your audience is the best way to successfully perform your text."

Learning to solve problems. The students also learned to be active problem solvers. Many described how they handled a critical incident at the club. These situations included supporting how the YC members selected partners, finding ways to motivate participation, and developing strategies for handling disruptive behavior. For example, one student was concerned that a YC member seemed uninvolved in the action, considered why she might be less eager to participate, and developed a plan to help the YC member to join the project. As the semester progressed, the students worked hard to facilitate the activities and to solicit actively YC member participation. These actions also illustrate the emergence of leadership skills. The university students said: "Leadership was a role the students had to step into every time we went to the club" and "I had to develop the ability to keep my composure in all situations and to handle distractions." They also acknowledged the impact their leadership had on the young YC members:

The kids look up to us as leaders of our group, but we as leaders constantly asked for input from the kids. When we asked the kids how they wanted to perform the poem each of them took their turn demonstrating something. Sometimes they would be bashful, but we would encourage them to contribute, and they did.

If educators and activists are looking to develop critical and social consciousness - one that leads to social transformation - then they must identify techniques to nudge students along the path of personal and social awareness. In this case, performance studies compliments servicelearning to assist students in the development of a personal and cultural awareness that often precedes actions that bring change. As the students created performances and used performance as a process, they acquired an awareness of their community and the impact they might have in the community. In addition to noting how the project shifted their thinking, they noted the impact the project had on their classmates: "I heard repeatedly 'didn't know kids could think about that,' or 'I didn't know kids did things like that."' Although "critics question whether merely 'exposing' students to social problems is a useful and ethical way to stimulate dedication to social justice and commitment to action" (Novek, 1999, p. 235), students certainly cannot act without an awareness that action is needed. At the least, such exposure can initiate a shift from self to other, a first step toward becoming a responsible community member. 


\section{Utopian Performances Provoke Action}

While changing individuals and raising social consciousness is a first step toward a utopian performance, actual social change is not possible unless people act. Individuals need reflexivity about their own behaviors - and those of others - and strategies to accomplish the desired aims. In short, they need to become active agents rather than passive recipients. Utopian performance, like Conquergood's (1992) performance as kinesis, provokes action and change in thought and deed.

Changing stereotypical thoughts. In this project, the students altered their thinking about children and peers, and that alteration led to a change in how the students related to and worked with the young YC members. Many of the university students had never interacted with young children, unless they had younger siblings. Some students recognized children as individuals for the first time: "I think it is a real honor to work with these kids, because they are interesting little people. They have strong personalities and I realize you have to treat each child a little different." In some instances, the work prompted a reconsideration of their classmates, whom the students typically regarded as friends they know well:

One thing I noticed wasn't the children's performance but the performance of the college students. It was interesting to see a variety of roles. Some did not know how to talk to children and so they stood off in the distance.

Others had definite stereotypes about children, and these stereotypes shifted over time. They remarked on how children of different ages responded to directions differently, and they admitted to adopting more specific instructions when leading them through an activity. They noted how the project caused them to "develop a patience I didn't know I had," to use "clear and concise" language, and to expect honesty: "They will tell anyone what they think. Children are totally honest. They have not learned to mask what they are really thinking." The university students altered their communication in specific ways: "You really don't have to talk down to them like I thought we would. I have come to learn they are pretty smart." The university students also learned they could ask more of the YC members because they recognized the creativity of these young people. In one performance, a YC member used a scrap of material to create different objects as she told a story. One university student wrote:

I think it is crazy how creative these kids can be and at their age. There were a few ideas that the kids came up with that were really cool, and I knew that I could start challenging them more.

Articulating personal agency. Another key change demonstrated by the university students is connected to a renewed investment in their own education. Students began to actively seek ways to improve the project and to connect their project with other courses and personal interests. In this instance, performance took on aspects of the utopian as a process that empowered them intellectually and socially. First, the students recognized the project as a space they could influence, rather than a place dominated by the professor. One student wrote:

We seem to have been given a lot of leeway. I felt that if anyone in our class suggested something, we could have tried it. It was a very open environment that was conducive to collaborative work. I recognized that I became more comfortable and started making suggestions.

Other students empowered themselves to research activities to be used in the sessions instead of looking to the professor to provide the program. Students shared how they "looked up some other games we could play that would work in our situation" and considered the overall structure of the sessions. They sought connections between this project and their other interests: "I had read an article about how thousands of major league baseball players grew up at the center, so when I learned we were working with them, I immediately got on the webpage and found information about their services and projects." Furthermore, the students identified this project as central to a more active strategy for learning: "This class compels me to become a more active contributor to my education as well as the community. I am able to apply what I have learned in a real life situation in my work."

Rethinking the value of performance. This project also increased the students' ability to reflect on and alter thought patterns when it came to assumptions about performance. The students recognized their own shortfalls in the execution of the assignment and developed plans to prevent something similar happening in a future performance. One student wrote:

I was honestly I was not prepared to do it. Because I was not prepared, I probably did not hold the children's attention. I was only concerned with performing and finishing as quickly as possible. Next time I must look for ways to draw them in.

Nearly every student in the project indicated an emergent recognition of their own assumptions or 
stereotypes and privilege. Prior to their first visits, the location of the club, in particular, fueled stereotypes about the neighborhood, but that changed after the first session:

The neighborhood outside doesn't seem to represent the feelings inside the center. By looking at the neighborhood and the kids around the neighborhood you would think the kids would be cold and not respectful. But they are. They seem to be good kids.

Other students wrote the YC members were smart and "more receptive to things" than they thought they might be. One student wrote: "For the most part I was expecting to have to be around a ton of out of control kids who didn't listen to a thing people said and who did what they wanted. This was not the case." By working with YC members, the students recognized their own stereotypical thinking and adopted behaviors to "not be so narrowminded about what I can learn from children."

Confronting personal privilege. In addition to facing their own stereotypes about others, the university students confronted their own privilege. Many talked about their own "sheltered" childhood and how the project opened their eyes to the experiences of others: "It opened my eyes to see there are kids out there who don't live in perfect neighborhoods like the ones in movies." One student, who self-identified as "from an inner city," said:

$[\mathrm{M}]$ ost in our class haven't had to deal with people with a different cultural background. It helped that two of our classmates were African American, but it was interesting to see the white guys in our class as a minority since most of the [YC] boys were African American or biracial.

The students also began to identify when others used stereotypes, and they critiqued others for making assumptions about the club:

I told a couple of guys I was going [to the club] and both said that I better "watch my hubcaps" or "don't go there after dark." I found that to be untrue, and I told them so when I saw them the next time.

One student thought the project might "blur the children's misconceptions" about attending college: "Seeing a class of college students of mixed ethnicities come and interact with them and then getting to visit college themselves allows them to believe they could go to college."

Learning about cultural difference. The students also noted various kinds of cultural learning - how to associate with a six-year-old, how to have fun with little money and much imagination, and how cultural difference has an impact on who we are, how we behave, and what we believe. For example, one international student explained: "My culture emphasizes group consensus. I typically become silent when I do not understand instead of asking questions. The activities reminded me of my cultural values as it showed me how I behave in certain situations." Many students talked about the project as "expanding their cultural horizons" and as a way to "create a positive attitude on life, age, and different cultures by focusing on something other than our own lives." Many of the project's skeptics admitted they were wrong about the value of cultural difference: "I was pretty skeptical about performance and culture going hand in hand; however, demonstration is often the best teacher and this has been proven to me." They noted class differences: "[T]hese kids are more grown up and have different interests than those of us who have been pampered with luxury. I can take this experience and learn differences in American culture." In addition, they explained the impact of race:

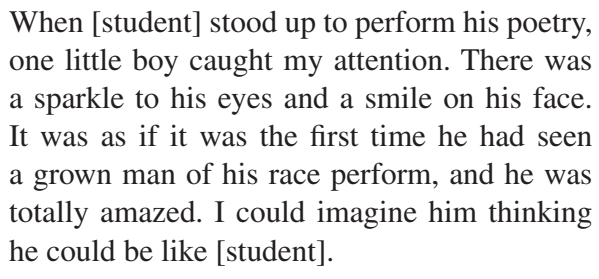

While they recognized the importance of and complexities around cultural difference, students also identified points where difference did not matter:

I had never been in the "projects" before and I
had a few reservations about what I might en-
counter. But these kids didn't know how out of
place I felt in their home. All they knew was
that I was from [college] and there to work
with them.

Just as performance has the potential to create personal and social change by creating awareness, performance has the capacity to expand the scope of change when it encourages a shift in behavior. By using performance, we establish the utopian impulse in students, who modify behavior with actions that can positively affect their community.

\section{Utopian Performances Are Interventions}

Utopian performance becomes an intervention when it generates an action marked by an urgent, solid commitment for change. In this sense, the 
change is not merely immediate but a pledge to integrate that change in future endeavors. The students in this project described ways to take their new understandings forward on both personal and social fronts. Performance instilled or restored their agency as subjects.

Committing to personal change. The students made immediate commitments to personal changes. These personal changes included thinking about how to get more children involved in the activities, being "less narrow minded," getting the children more interested in the stories by way of performance techniques, and demonstrating an energy and enthusiasm that would be infectious to other participants. Some changes were skill-oriented. For example, many students committed to a new approach to time management. The students did not merely recognize they had a problem with time management; they committed to a different strategy for managing time better:

Time management is something I have struggled with throughout college. By doing things like going to the club and performing with a time limit I know I must regulate my time wisely. I need to focus on the things I need to get done. I have started creating a list of my objectives on a daily basis.

This student identified a problem, determined a solution, and then committed to new patterns of behavior. Others who cited time-management problems were just as determined to not wait until the last minute, and they also developed a schedule for each project.

Taking ownership of community-based projects. The students also communicated dissatisfaction with previous community work as more passive than our project and created a plan for communitybased work in the future: "I mailed a letter yesterday I received about doing volunteer work with the university. I wish I had done something before now, but this is a right step." The students pledged to make time to work with youth in this organization and others after the semester ended. One student wrote: "I remember some students saying they felt scared because of the area, and a few visits later they were going over on their own time."

The students also developed plans beyond their personal actions. Many said the class should be a yearlong project. They decided that if every class participated, the project could involve a weekly event. Many became advocates for this type of experiential, service-based learning:

All students should be assigned to do some type of service-learning projects while in school. This would help students learn on their own to assess problems and attempt to fix them, make connections within their own community, and to help others as they help themselves intellectually. Students would thrive in every aspect of their lives and understand how to help each other.

Perhaps the most interesting change the students demonstrated was their own sense of social agency when considering their current education and future endeavors. Many recognized this project as an opportunity to apply what they "learn in the classroom in real world situations" so the "benefit of learning is seen incredibly fast." Another explained:

I have never before been able to clearly define what I learned from the class based on the goals until this one. That is not to say I haven't taken classes with well-defined goals, but it is to say that I have never really had the critical ability to evaluate the process I took part in. The assignments helped guide me through the critical thinking necessary to recognize what I was actually learning.

Other students noted the project as a link between the campus and community. Several described college students as "losing the real-world aspect of things" because they sit in a classroom and perform tasks such as reading and writing to learn various subjects. However, by getting out of the classroom and learning in a real-world environment, students can learn in a different way that may have more of an impact.

As one student wrote: "If the community is going to change for the better, it is going to because of the actions of the people living in it." Utopian performance is a social intervention empowering participants to be responsible agents for the community in which they live and work. When students use the performance process as a mechanism for community empowerment, we see additional outcomes. Students become aware of community issues and take on roles as active citizens with power to affect change. They embrace an embodied methodology - one requiring mental and physical abilities - to understand community and the impact of service. They create a vision for a better community, one steeped in understandings generated in and by performance. They also assume responsibility for their own education as collaborators in a process dependent on critical thinking and experiential learning. As one student wrote: "This is not to say that every student who does this will run out and do something in the community. But it does say we have greater potential to become involved if it starts with class-assigned work." 


\section{Performance Praxis Is Not Perfect}

Performance, then, is a process for realizing the utopian potential in students and our communities. However, just as all students may not incorporate service and civic engagement into their lives once they leave the academy, some pedagogical practices "may be more conducive than others . . . such norms and practices offer no general guarantee" (Frey, Pearce, Pollock, Artz, \& Murphy, 1996, p. $110)$. The evidence gathered and assessed in this project has firmly established the benefits of using service-learning and performance as a mechanism for realizing and for generating a utopian impulse. However, $4 \%$ of the field reports indicate room for improvement in terms of guiding students toward a more sophisticated consideration of what they do, who they are, and how they think. Thus, while we can easily point to the power of performance to resist, we must recognize it has power to reproduce that which it seeks to restrain.

Expressing gratitude for one's advantage. Some students indicated a renewed gratitude for their own lives and family. Certainly developing an appreciation for one's advantages - particularly those that come not from one's deeds but from one's demographic - is important. Some of the responses, however, never moved beyond "I appreciate what my mother and father have given me," "I am truly lucky for my nice car and home and wonderful parents who have done everything for me," or "seeing these kids makes me count my own blessings." When students made these kinds of comments, they rarely recognized the impact of economic disparity, nor did they critically engage to consider issues related to social injustice. Some students noted they lived in what Frey et al. (1996) calls a "society of abundance" (p. 111); yet, they stopped short of acting on their recognition. In this instance, performance protected their privilege and further separated them from the YC members. They were just thankful to not be in the position they saw the YC members occupy.

Making assumptions about others. A related negative response entailed the sympathy students occasionally used when making assumptions about the lives of the YC members. Performance, of course, has long considered sympathy an important theatrical staple; however, Augusto Boal (1985) has argued such sympathy prevents a battle against the status quo. Instead, audience members identify with the protagonists, forgive them for all their misdoings, and leave the theater purified. For this community-based project, sympathetic responses meant noncritical approaches to the social experience. In other comments, some students assumed these YC members came from "broken homes," "never got new toys and clothes," and lacked encouragement to achieve. These comments reflect a noncritical thought process, one packed with stereotypes, assumptions, and privilege. The last examples of this category take on a self-congratulatory tone: "The people who receive the help really appreciate the effort," "We really stepped up for these children," "We really had a profound effect on these children," and "We really made their day." When students made these kinds of comments - ones that reflect noblesse oblige - they perpetuated the stereotyping that blocks cultural understanding.

Conceding defeat. While nearly every student admitted the project caused them to think more clearly about the course content, introduced them to social agencies, and directed their attention to community engagement, three students expressed an understanding of social needs but were too overwhelmed by those needs to approach a solution. Although many pledged to be involved in and assumed agency and ownership of the activities, two students thought these kinds of projects were "lofty" because "they can't help everyone." One thought, for example, "we would have been better off raising money to provide them resources" and concluded the project did not meet the needs of the club. Student awareness in this example did not move beyond a charity model (Artz, 2001) as the students did not discern the difference between giving donations and connecting with community members. Instead, these remarks further disenfranchised the children by detailing what the students thought the YC members needed.

These negative responses, 18 of the 452 documents examined, might be explained in a number of ways. First, students may not have been adequately prepared for the work. Perhaps the classroom discussion and related reading assignments did not provide an explanation about the role of service-learning. Although the responses were not coded according to academic standing and most of the students enrolled in the course were juniors or seniors, the class was a 200-level class open to sophomores and above, so younger students may not have been mentally or emotionally prepared for this level of critical learning. These negative responses indicate important challenges to planning and implementing service-learning projects. This project reminds educators of the need to develop structures and forms that resist the banking model of education while providing some structure for students. Millennial students, for example, seem to have a better service-learning experience when they are explicitly told why they are doing certain activities and projects; educators can provide that 
information while leaving the question of how unanswered so that students are solving problems and making meaning. Such transparency also reduces the uncertainty students experience. Another consideration entails addressing emotional awareness in addition to cognitive awareness, the goal of most college educators. That is, in addition to considering the intellectual impact - course concepts as well as those related to social justice - one must consider the emotional impact a project might have on students and how they might respond to the experience. If we want students to better understand diverse people and experiences such as poverty, discrimination, and cultural difference, we must provide them with a more complete foundation to process the experiences they encounter along their journey to understanding. In addition, we must provide them with a model for empathetic reciprocity so that interactions empower and activate them. A final consideration is the span of the reflection. The students wrote short reflections within two days of each field visit; at the end of the 16-week semester, they wrote a longer paper that discussed the experience more holistically. Certainly changes were seen between the short reflections and the longer one, as students had a longer span of time for ideas and understanding to percolate. Sigmon (1996) has suggested that this long-term view of reflection, a process which may occur over time rather than as an immediate response, is significant to understanding the impact of service-learning.

However, this research also points out the need for a better understanding of how to connect pedagogy to social justice so that the work we do in the classroom increases social awareness about social justice while encouraging action that attains social justice goals. Certainly we want students to recognize systemic inequities in how power and resources are distributed, but also we want to foster the belief they can be agents for change in their communities and to provide them confidence and a model for how to participate in their community so that change occurs.

Civic duty, civility, and kindness are qualities essential to utopian societies; however, students also need to blend those qualities with a critical awareness of difference and an urgent motivation to make a difference. This project was successful in making unfamiliar what the students thought they knew, much in the way of Brecht and Bentley's (1961) alienation-effect; the performance process interrupted their understanding of their community and those who share that space. Being on-site, in particular, required them to rethink old positions, perhaps ones they had assumed because their family and friends shared them. The students recognized they could implement small practices that affect the local level. Their success has the potential - if their statements of committed action are an indication - to demonstrate what can be achieved when people invest their time and energy to be a force for change.

Documenting our successes in the classroom and community is important; however, we must also examine the pitfalls of what we do and make thoughtful changes to maximize the opportunity to achieve success as educators and activists. As Eyler (2002) has suggested, we must research and revise our teaching as we assess its ability to accomplish learning and service goals. In the same way that we are critical when it comes to research, we must also apply that critical process to our pedagogy, especially when we include community-based projects. The border-crossing Zlotkowski (1998) describes - connecting theory to application and campus to community approaches - must be characteristic of the most productive service-learning structures. After all, such a strategy recognizes the impact felt by multiple stakeholders with diverse needs and interests.

As an embodied form, performance offers students the opportunity to practice strategies to achieve their version of community. As a "triad of theory, method, and event," performance displays knowledge in the tradition of a dialogic inquiry packed with potential to shake the human consciousness (Madison \& Hamera, 2006, p. xii). Performance is a tool for and evidence of utopian potential, and in conjunction with service-learning, it, too, can "educate imaginations of students" so they can question social and cultural narratives and make choices to generate a different, more perfect society (Conville, 2001, p. 184). Performance and service-learning are effective strategies for implementing critical pedagogies, demonstrating a personal commitment to social transformations, and illustrating publicly one's civic obligation to a democratic society.

\section{References}

Alexander, B. K. (2006). Performance and pedagogy. In D. S. Madison \& J. Hamera (Eds.), The SAGE handbook of performance studies (pp. 253-260). Thousand Oaks, CA: SAGE.

Artz, L. (2001). Critical ethnography for communication studies: Dialogue and social justice in service-learning. Southern Communication Journal, 66, 239-250.

Boal, A. (1985). Theatre of the oppressed (C. McBride \& M. O. McBride, Trans.). New York, NY: Theatre Communication Group.

Boal, A. (1992). Games for actors and non-actors (A. Jackson, Trans.). New York, NY: Routledge. 
Boal, A. (1995). The rainbow of desire (A. Jackson, Trans.). New York, NY: Routledge.

Boal, A. (1998). Legislative theatre: Using performance to make politics (A. Jackson, Trans.). New York, NY: Routledge.

Boal, A. (2001). Hamlet and the Baker's son: My life in theatre and politics. New York, NY: Routledge.

Brecht, B., \& Bentley, E. (1961). On Chinese acting. The Tulane Drama Review, 6, 130-136.

Capo, K. E. (1983). From academic to socio-political uses of performance. In D. W. Thompson (Ed.), Performance of literature in historical perspectives (pp. 437-457). Lanham, MD: University Press of America.

Cattanach, A. (1992). Play therapy with abused children. London, England: Jessica Kingsley Publishers.

Chesner, A. (1994). Dramatherapy and psychodrama: Similarities and differences. In S. Jennings, A. Cattanach, B. Meldrum, S. Mitchell, \& A. Chesner (Eds.), The handbook of dramatherapy (pp. 114-132). New York, NY: Routledge.

Conquergood, D. (1992). Ethnography, rhetoric, and performance. Quarterly Journal of Speech, 78, 80-97.

Conville, R. L. (2001). Service-learning and the educated imagination. Southern Communication Journal, 66, 183-186.

Creswell, J. (1998). Qualitative inquiry and research design: Choosing among five traditions. Thousand Oaks, CA: SAGE.

Denzin, N. K. (2006). The politics and ethics of performance pedagogy: Toward a pedagogy of hope. In D. S. Madison \& J. Hamera (Eds.), The SAGE handbook of performance studies (pp. 325-338). Thousand Oaks, CA: SAGE.

Dolan, J. (2005). Utopia in performance: Finding hope at the theatre. Ann Arbor: University of Michigan Press.

Eyler, J. S. (2002). Stretching to meet the challenges: Improving the quality of research to improve the quality of service-learning. In S. H. Billig \& A. Furco (Eds.), Service learning through a multidisciplinary lens (pp. 3-13). Greenwich, CT: Information Age Publishing.

Fisher, B. M. (1994). Feminist acts: Women, pedagogy, and theatre of the oppressed. In M. Schutzman \& J. Cohen-Cruz (Eds.), Playing Boal: Theatre, therapy, activism (pp. 185-197). New York, NY: Routledge.

Fisher, B. M. (2001). No angel in the classroom: Teaching through feminist discourse. New York, NY: Rowman \& Littlefield.

Fox, J. (1986). Acts of service: Spontaneity, community, tradition in the nonscripted theatre. New Paltz, NY: Tusitala Publishing.

Freire, P. (1968). Pedagogy of the oppressed (M. B. Ramos, Trans.). New York, NY: Herder \& Herder.

Frey, L. R., Pearce, W. B., Pollock, M. A., Artz, L., \& Murphy, B. O. (1996). Looking for justice in all the wrong places: On a communicative approach to social justice. Communication Studies, 47, 110-127.

Fuoss, K., Kistenberg, C., \& Rosenfeld, L. B. (1992). "OUT ART": Reducing homophobia on college cam- puses through artistic intervention. Text and Performance Quarterly, 12, 349-361.

Giroux, H. (1989). Schooling as a form of cultural politics: Towards a pedagogy of and for difference. In $\mathrm{H}$. Giroux \& P. McLaren (Eds.), Critical pedagogy, the state, and the cultural struggle (pp. 125-151). Albany: State University of New York Press.

Giroux, H. (1992). Border crossings: Cultural workers and the poetics of education. New York, NY: Routledge.

hooks, b. (1994a). Eros, eroticism and the pedagogical process. In H. Giroux \& P. McLaren (Eds.), Between borders: Pedagogy and the politics of cultural studies (pp. 113-118). New York, NY: Routledge.

hooks, b. (1994b). Teaching to transgress: Education as the practice of freedom. New York, NY: Routledge.

HopKins, M. F. (1995). The performance turn - And toss. Quarterly Journal of Speech, 81, 228-236.

Howard, L. A. (2004). Speaking theatre/doing pedagogy: Revisiting theatre of the oppressed. Communication Education, 53, 217-233.

Howard, L. A. (2013). Expressions of experience and transformation: Performing illness narratives. Text and Performance Quarterly, 33, 113-150.

Jackson, T. (Ed.) (1993). Learning through theatre: New perspectives on theatre in education ( $2 \mathrm{nd}$ ed.). New York, NY: Routledge.

Kolb, D. A. (1984). Experiential learning: Experience as the source of learning and development. Englewood Cliffs, NJ: Prentice Hall.

Langellier, K. (1986). From text to social context. Literature in Performance, 6, 60-70.

Langellier, K. M. (1983). A phenomenological approach to audience. Literature in Performance, 3, 34-39.

Langellier, K. M. (1999). Personal narratives, performance, and performativity: Two or three things I know for sure. Text and Performance Quarterly, 19, 125-144.

Long, B. W., \& HopKins, M. F. (1982). Performing literature: An introduction to oral interpretation. Englewood Cliffs, NJ: Prentice Hall.

Madison, S. D. (1998). Performances, personal narratives, and the politics of possibility. In S. J. Dailey (Ed.), The future of performance studies: Visions and revisions (pp. 276-286). Annandale, VA: National Communication Association.

Madison, S. D., \& Hamera, J. (2006). Performance studies at the intersections. In D. S. Madison \& J. Hamera (Eds.), The SAGE handbook of performance studies (pp. xi-xxv). Thousand Oaks, CA: SAGE.

Mann, C., Hecht, M., \& Valentine, K. (1988). Performance in a social context: Date rape versus date right. Central States Speech Journal, 39, 269-280.

Meillo, J. (1990). Issues of Milieu therapy: Psychodrama as a contributor to the treatment of a case of anorexia nervosa. In P. Holmes \& Marcia Karp (Eds.), Psychodrama: Inspiration and technique (pp. 137-154). London, England: Routledge.

Meldrum, B. (1994). Historical background and over- 
view of dramatherapy. In S. Jennings, A. Cattanach, B. Meldrum, S. Mitchell, \& A. Chesner (Eds.), The handbook of dramatherapy (pp. 12-27). New York, NY: Routledge.

Miller Rassulo, M., \& Hecht, M. (1988). Performance as persuasion: Trigger scripting as a tool for education and persuasion. Literature in Performance, 8, 40-55.

Moreno, J. L. (1946). Psychodrama (2nd rev. ed.). New York, NY: Beacon House.

Novek, E. M. (1999). Service-learning is a feminist issue: Transforming communication pedagogy. Women's Studies in Communication, 22, 230-240.

Rich, M. D., \& Rodriguez, J. I. (2007). A proactive performance approach to peer education: The efficacy of a sexual assault intervention program. In L. R. Frey \& K. M. Carragee (Eds.), Communication activism, Volume 2: Media and performance activism (pp. 315344). Cresskill, NJ: Hampton Press.

Rohd, M. (1998). Theatre for community, conflict, \& dialogue. Portsmouth, NH: Heinemann.

Roloff, L. (1983). Performer, performing, performance: Towards a psychologicalization of theory. Literature in Performance, 3, 13-24.

Sigmon, R. (1996). The reflective arts. In R. L. Sigmon \& S. G. Pelletier (Eds.), Journey to service learning: Experiences from independent liberal arts colleges and universities (pp. 37-41). Washington, DC: Council of Independent Colleges.

Strauss, A., \& Corbin, J. (1998). Basics of qualitative research: Techniques and procedures for developing grounded theory (2nd ed.). Thousand Oaks, CA: SAGE.
Strine, M., Long, B. W., \& HopKins, M. F. (1990). Research in interpretation and performance studies. In G. M. Phillips \& J. T. Wood (Eds.), Speech communication: Essays to commemorate the seventy-fifth anniversary of the speech communication association (pp. 181-204). Carbondale: Southern Illinois Press.

Trend, D. (1992). Cultural pedagogy: Art/education/politics. New York, NY: Bergin \& Garvey.

Turner, V. (1988). Anthropology of performance. New York, NY: Performing Arts Journal Press.

Williams, D. (1983). From academic to psycho-social uses of literature. In D. Thompson (Ed.), Performance of literature in historical perspectives (pp. 419-435). New York, NY: University Press of America.

Wirth, J. (1994). Interactive acting: Acting, improvisation, and interacting for audience participatory theatre. Fall Creek, OR: Fall Creek Press.

Zlotkowski, E. (Ed.). (1998). Successful service-learning programs: New models for excellence in higher education. Boston, MA: John Wiley \& Sons.

\section{Author}

LEIGH ANNE HOWARD (Ph.D., Louisiana State University) is Professor of Communication Studies at the University of Southern Indiana. Her research interests include the performance of personal and social identity, as well as the social impact of community-based and interactive theatre. 